\title{
Aisthesis
}

Firenze University Press

www.fupress.com/aisthesis

OPEN ACCESS

Citation: D. Cecchi (2021) Pandemic and the Fairy Tale Narrative. Aisthesis 14(1): 37-43. doi: 10.36253/Aisthesis-12499

Copyright: @ 2021 D. Cecchi. This is an open access, peer-reviewed article published by Firenze University Press (http://www.fupress.com/aisthesis) and distributed under the terms of the Creative Commons Attribution License, which permits unrestricted use, distribution, and reproduction in any medium, provided the original author and source are credited.

Data Availability Statement: All relevant data are within the paper and its Supporting Information files.

Competing Interests: The authors have declared that no competing interests exist.

\section{Pandemic and the Fairy Tale Narrative}

\author{
DARIO CECCHI
}

\begin{abstract}
The article considers how the narrative of the pandemic has been developed, especially with regard to literature. The case study analyzed is the Italian novel L'assemblea degli animali, written by an anonymous author, whose penname is Filelfo. The article shows that the wide range of classical, literary and artistic references recognizable inside the text corresponds to a precise attitude of the ecologist culture, which is in search for traditional and elevated models to assert their ethical and political objective. The novel brings this directory to the point that it evokes an esoteric dimension of ecology. The article states that this stance is not serious, but ends into a literary game and feeds the needs for entertainment by the cultural industry, rather than giving any real contribution to the ecological question.
\end{abstract}

Keywords: ecology, literature, entertainment, cultural industry, esoterism.

\section{THE ECOLOGIST NARRATIVE}

The representation of the pandemic through images has shown a poverty that does not allow the elaboration of narrative formulas that are completely appropriate to the situation (see Cappelletto [2021]). If we look at the journalistic account of the pandemic, it seems that journalism is increasingly rediscovering speech, after years of uncontested domination of images. It is interesting to note that, at this juncture, genres such as the Bildungsroman or the didactic fable are making a comeback. I would like to consider in particular a literary case, which will let me reflect precisely upon this aspect: the forms of narration that are emerging, or re-emerging, during the pandemic indicate a renewed role of literature.

However, I refrain from formulating a general thesis on the narrative forms of the pandemic, whether it concerns literature or cinema. In short, I avoid suggesting delays or foresight of this or that art. I will limit myself to pointing out how for instance, in the period preceding the pandemic and with regard to a now flourishing activity like documentary, cinema does not seem to have reacted in a striking way to this event - except of course wondering about the 
limits of its medium in conditions of lockdown. On the contrary, the ecological question, as emerges in the work of many remarkable directors, of which I will mention only the name of Nossiter, had been deepened by cinema. It is also interesting to see how, once an epidemic has broken out and spread all over the globe, the same interpretative model has often been proposed, that is, the rediscovery of traditions and a lifestyle more respectful of a 'natural order'. A sort of revolutionary claim is linked to this model, however revolution is intended, and is meant to be a sort of reparative action. Omelia contadina (2020), the recent film realized by Alice Rohrwacher in collaboration with street artist JR, goes exactly in the same direction, despite being released when the global ecological agenda is now having to deal with the pandemic.

It seems to me that cinema - I repeat: taken in its most widespread expressions and subject to every possible exception - has not reacted fully adequately to the novelty of the event, believing to be able to treat the pandemic as a continuation of the discourse already started on the subject of other issues: the ecological question, but also the question of globalization understood as the cancellation of distances. Thus, while films on ecology continue to focus on the disasters of the Anthropocene, the issue of physical distancing during confinement is mostly dealt with as a variant of the incredible virtual approach now within the reach of almost everyone (at least in the West), thanks to new digital devices. This problem, in other words, is addressed in terms of a more or less effective and attractive remodeling of social media (Facebook, Instagram and others) and communication technologies (Skype, Whatsapp and now Zoom, Meet etc.). And it is no coincidence that some documentary experiments concerning the lockdown took direct inspiration from a film model that marked the advent of the internet in the world: I am referring to Life in a Day (2011) by the Scott brothers, in which the directors had he asked people around the world to film a fragment of their day. They would then edit parts of these videos together, thus creating an ideal day for humanity across the globe. I speak of a model because the experiment was replicated by Gabriele Salvatores with his Italy in a Day (2014), which limits the perspective to Italy. However, it seems to me that in the experiments indicated above there is always the risk of activating the mechanism of what Grusin calls premediation. I am of course referring to how certain themes or narrative models were taken up after the outbreak of the pandemic. It is not so much the fact that familiar narrative formulas are repeated: the thing in itself is neither an evil nor an indication of little attention to current events. The point is that narrative themes and frames are repeated: in other words, the contexts of the narrative ${ }^{1}$ have not been reworked in any way. But it is not fully accounted that, due to the overlap between narrative and information about the pandemic, such marked narrative continuity can end up providing the feeling that the pandemic is somehow within the number of foreseeable events. In short, the trauma of the event is anesthetized (see Montani [2007]), but, due to a perverse effect, this anesthetization creates even more anger, because it supports the idea that the pandemic could have been avoided ${ }^{2}$. In summary, the visual narrative of the pandemic has not always promoted a new understanding of reality ${ }^{3}$. The effect of the sense

${ }^{1}$ I use the notion of "context" in the meaning proposed by Umberto Eco (1979), which distinguishes context and "cotext". The cotext is all that we find on the surface of the text and that contributes to the understanding of the cell we are dealing with. To a minimum degree, this is what we need to understand the different use or sense of the preposition "of" depending on whether we are talking about "Elizabeth of England" or "bottle of wine". The context is, so to say, the background that is necessary for us to understand what is said in the text: the phrase "they brought the lion back to the cage" presupposes the existence of a city with a zoological garden or a circus that is camped somewhere.

${ }^{2}$ Of course, I do not want to say that this forecasting work, for example by science, is not desirable and commendable: it is in every respect. But the problem here is the communication, direct or indirect, in the form of information or narration (of reality or fiction), of how we are coping with the pandemic, with what technical means, with what strategies and projects, with what scientific tools.

${ }^{3}$ For the reciprocal implication and the intertwining of understanding and narrating, see Garroni (2003), who thinks of this relationship as a "paradox" [Garroni (2003): 175] together irre- 
of narration on understanding is basically the expansion, on the level of the imagination and its ability to anticipate an intellectual grasp of reality, of the art process described by Sklovskij (1968) as "estrangement". Except that here not only the renewal of perception and therefore its flagrance is at stake, but also the possibility of experiencing things, that is, of bringing them back to a possible sense, even in the absence of specific practical or cognitive discoveries (see Garroni [2005]). In this perspective, the idea of narrating as a possible anticipation of the sense of experience refers to an investigation of the ways and forms through which the subject makes an image of the world. Given these premises, it cannot be said that, in cinema, a similar reconfiguration of meaning, with respect to the ecological question or the media question, has emerged in a recognizable way, even though it is evoked in numerous videos or films. Take the question of the "spillover", or leap of the virus from one animal species to another, in this case to the human being. This scientifically attested fact has an undoubted narrative potential: that is, it invites not to a didactic exposition of the scientific meaning of the concept, but to a narrative development of a spillover case and its catastrophic consequences, as it is hypothesized that it happened in the case of Covid-19. In other words, it would be a very powerful accelerator in the process of configuring the story, of what Paul Ricoeur (1983: 125-135) calls "Mimesis 2". As we will see in the next paragraph, this happens, surprisingly indeed, in a novel, or rather a "fairy tale", released at the end of 2020.

\section{THE ANIMAL FAIRY TALE}

The fairy tale mentioned at the end of the previous paragraph is L'assemblea degli animali [The Assembly of Animals], released in the original Italian edition by Einaudi in November 2020, whose subtitle reads Una favola selvaggia [A Wild Fairy Tale]. The anonymous author uses a nick-

ducible to explanations in a strictly logical sense and yet necessary. name, "Filelfo", on whose meaning he will offer an explanation at the end of the book. I will have to return to the fable-like nature of the story later. Let us start with the construction of the weave. In fact, the story is thought of as a sort of mythical explanation of the reason why the virus spillover from a bat to a human being. The explanation provided is linked to the ecological theme of the revolt of nature against the abuse perpetrated by mankind, but introduces some original elements. In fact, throughout the first part of the book (Chapters I-IX), the author imagines that animals gather in assembly to decide what to do with an increasingly aggressive and voracious human being. The casus belli was given by the terrible fire that devastated the forest in Australia, causing a terrible slaughter of animals and the destruction of their environment. The book opens with a description of all the animals that gather in the secret place of the assembly, known to all animals from the moment of birth, to decide what to do. Only the human being has forgotten the existence of this place. The scene is effectively outlined: it is the spectacle of nature that is both the setting for the meeting and it is itself, represented by all animal species, that comes together. It is a cosmic movement that narrated. The poet's words would fit well with its bucolic and epic development: redeunt Saturnia regna. Here too, the ferocious beast stands next to its prey, not because a kingdom of peace has been established among the animals, but because, the book informs us, it is the eternal rule of this assembly that the fundamental law of nature is suspended: say the law of the strongest. I suggested to make a comparison between the fable of Philelf and the IV Virgilian Eclogue - si parva licet. In fact, the assembly of animals is teeming with cultured references, not least to the Greek-Latin classics. Curiously, however, the bucolic Virgil is absent, at least explicitly. The author has in fact accompanied the book with a thick appendix of annotations in which, chapter after chapter, he indicates the more or less hidden or evident references of his to other texts. The author's cultural encyclopedia - if I can express myself thus, paraphrasing a notion bor- 
rowed from Umberto Eco (1979) - could not be more extensive. It goes from classical literature to contemporary writers: Italo Calvino is mentioned several times; Borges is referred to as the greatest modern poet. But there are also references as much to pre-classical mythologies as to pop culture, with quotes taken for example from the songs of Fabrizio De André. A similar heterogeneity suggests to a first critical reading a judgment that sees in the story a sort of pastiche covered by the aura of the allegorical fable. But, beyond the critical judgments, I am interested in establishing, in the wake of Eco's theory of cooperation, if it is possible to trace the identity of the author and establish who they are addressing, who their audience is. Naturally, the reference to Eco goes in this direction, the interest is not so much for the real identity of the mysterious Filelfo, but for the "model author" that this story presupposes. Similarly, I am interested in what could be, in the mind of the writer or at least in accordance with the narrative device they have created, the "model reader" they address. But before proceeding to examine the two issues, I will add the few other elements necessary to understand what I will want to say about the book.

The assembly, in which chiefs, the "kings" of the various elementary kingdoms (earth, air, sea, underground world; therefore: lion, eagle, whale, mouse) and the victims of human fury (the Australian koala), deliberates that the only possible solution is to hit the human being so as to make him reflect on what he is doing to nature and the rest of the animal world. It was therefore decided to accept the proposal of the king of mice to spread a virus that will hit humanity hard without annihilating it. This is obviously Covid-19, whose epidemic arises from a spillover from the bat (the winged mouse) to the human being through some well-known passages, which the author describes effectively as the future of history: the pangolin, bite from the bat, in the cage of the farmer's son who goes to the market to sell it. Everything happens in the most anonymous and insignificant events. The pandemic's direct witnesses in the story are obviously the white cat and the dog MoMo, representatives of the domestic species closest to the human being, from which they even rise to religious symbols (in Egypt) and literary figures.

MoMo and the cat see the point of maximum resistance of mankind in the progressive degradation of the life of people and families of which they are pets, until death from the virus of the owner of MoMo, of which we intuit that he was a doctor engaged in fight against the epidemic. The pain is such that the dog is transformed into a new being, a Filelfo in fact, half dog and half human. The "Filelfi" are those beings who have undergone a process of metamorphosis that makes them hybrids; hybridization is seen as access to a higher stage of existence, even of essence, similar to the ascension towards the astral constellations.

We can now formulate hypotheses on the identity of Filelfo. First of all, in order to understand who the author is, we need to understand what kind of text they propose to us. At first glance, L'assemblea degli animali, according to what has been said, would seem to be an initiatory fable. However, there are two elements that must lead us to be more cautious. Unlike other authoritative models of esoteric or key fable, just think of Goethe's Fabel, here the historical context in which the fantastic story is to be placed is clearly indicated: the immemorial time typical of the fable and of the epos disappears, which refer typically at the time of "once upon a time" or "no longer always", that is, they represent a world that exists and does not exist at the same time ${ }^{4}$ (see Bachtin [1981]). Furthermore, the precise reference to the sources taken from different auctores and inserted in the plot of the text is made sometimes for the sake of the quotation, as in the case of that "Last comes the Raven" (Filelfo [2020]: 5), explicitly taken up by Calvino, with whom the story opens. This takes away much of its esoteric character from the story. There are no enigmas to solve, a fundamental element in activating the operational procedure

\footnotetext{
${ }^{4}$ Persian fables, for example, do not begin with "Once upon a time" but with "Yeki bud wa yeki nabud" ("Once upon a time there was and there was not").
} 
through which the reader can start his or her initiatory path. Nor can it be said that the structure of the text constructed as a montage of citations of which the author indicates the sources functions here according to the authoritative model it evokes - and which is promptly cited among the numerous sources. I refer to Eliot's Wasteland. What is missing here, unlike Eliot's masterpiece, is the typically modernist intention of making the reader feel all the dissonant force that exists in approaching, for example, Madame Blavatsky and Tiresias. It is then up to the reader to elaborate - using a cinematographic metaphor, in the intervals of the montage - the meaning of what he has read.

Intertwining the two elements, the pastiche that refuses to give the reader reading instructions (Jameson [1991]) and the pulverization of time frames (Lyotard [1984]), both internal to the text and in relation to the possible "refiguration" of the reader's world (Ricoeur [1983]: 138-143), we could say that we are dealing with a product of late postmodernity, which, however, lacks the ironic trait typical of postmodern literature: it is not possible here to assert the clause according to which that's all folks! The fable is "wild", as the subtitle states, not so much because it operates a 'conversion' of the reader to the feral state, but because it offers a pastiche that can no longer be dismantled as it is immune to an ironic reading. Therefore, it is not an esoteric fable in the narrow sense of the word, but rather a successful Singspiel which, winking at themes and figures taken from the most disparate traditions, exhibits a variable rate of hermeticity. Therefore, despite the crowd of cultured references, the matrix of the story does not seem to come from literature and high culture but from entertainment and pop culture (Bolter 2020), in the highest and noblest sense of the term, which a well-thought-out Singspiel can guarantee. Consequently, Filelfo is not a Pythagorean sage, a hermit by his choice in some remote land of the Italian countryside, but rather the refined editor of a large publishing house.

We can now ask ourselves who is the model reader of Filelfo's "fable". Here is what the author themselves says at the end of the book, with words and cadences that emphasize its mysterious or esoteric character:

Sappi però che i nuovi giusti sono ovunque, confusi tra la gente comune, disseminati in tutto il mondo, persi in mille lavori e fatiche e problemi, a ricostruire umilmente, finché dura la terra, una nuova arca. Forse qualcuno di loro ora ha tra le mani questo libro e lo sta leggendo. Forse sei tu, lettore arrivato alle sue ultime parole. Che non possono che essere: de te fabula narratur. Perché da sempre la favola parla di te. Sei tu, lettore, l'autore di questa e della prossima. (Filelfo 2020: 140)

[But know that the new righteous are everywhere, confused among the common people, scattered all over the world, lost in a thousand jobs and hardships and problems, humbly rebuilding a new ark while the earth lasts. Perhaps some of them now have this book in their hands and are reading it. Maybe it's you, reader come to its last words. Which can only be: de te fabula narratur. Because the story has always been about you. You, reader, are the author of this and the next.]

The syntax, always fluid, has maintained an adequate level of hypotactic complexity throughout the text, such as not to discourage the average reader, without risking the accusation of simplification. In closing it becomes a little more complicated: subordinates and incisions increase. The sentence even breaks up and gives rise to two consecutive subordinates at the beginning of a proposition, connected in meaning with the previous proposition. Everything emphasizes the dramatic tone of the author's final considerations. Not only is the book about the reader, as we would feel to understand the saying de te fabula narrator, according to a lectio facilior. The fable belongs to the readers, in the sense that they are the authentic author, also in view of future extensions of history.

We draw the conclusion that the reader is the one who gives meaning to the unprecedented dissolution of the historical time of the pandemic in the mythical time of animal nature: readers are in fact the author of the present and future fable, 
as if the story had created a direct bridge, without mediation, between the world of fiction and the real world. From a similar perspective, the concrete author of the story can affirm the total reversibility between themselves and the reader: the invitation is to enter into a communion of ideas and a communion of intentions and feelings. The author is not Filelfo, but the newly formed brotherhood of the Filelfi, in which the reader is called to enter, becoming an author in turn. And the fable itself from a pure metamorphosis tale becomes an effective transformation action of a human race that must choose whether to embrace the project of a return to animality as a new frontier of moral and civil progress reformed according to the imperative of ecology. In this respect, the most powerful classic reference in the final part of the book undoubtedly goes to Ovid's Metamorphoses. In this sense, L'assemblea degli animali is not really an esoteric fable for initiates, but a sort of propaganda pamphlet for the layman, which uses a high style and classic models to gain authority among the reading public.

The point reached satisfies only in part, especially if we start from the assumption, widely requested by the story, that the "encyclopedia" the reader needs to interpret the text cannot be composed only of knowledge and notions, but must also include a bundle of feelings and inclinations, a wide-ranging sensitivity towards the themes of ecology and the protection of nature. The model reader of this story is not, in all respects, a scholar or a militant ecologist. The reader's culture is solicited in a broader meaning: not only his knowledge properly so called, but the set of informal knowledge, information and quasi-knowledge that contribute to forming his opinion. It could be said that this model reader, due to the culture and preferences attributed to him, comes from that middle or upper middle class with a progressive orientation, which lives in the centers of large urban agglomerations. We could almost speak of a "Limit Traffic Area" reader, to use a figure which has become popular in the Italian political debate. However, we must bear in mind that this popular journalistic category perhaps makes more sense on a cultural level than on a political one. Consequently, more than a model reader, L'assemblea degli animali implicitly draws the contours of a model environment of possible readers: it is in fact in the mechanism of imitation and emulation, in the sharing of cultural habits within the same social reality, which goes to place the fortune of this book. In the absence of salons and literary circles, we must imagine the relationship between the model author, behind whom we think there is the figure of an editor, and the model reader in terms of the relationship between spin doctor and blogger, that is, between professional and semi-professional actors of the same media system.

As argues Wolfgang Iser (2013: 228), elaborating a paradigm of interpretative cooperation more open to the assumption of the aesthetic elements of this performance, reading presupposes an "artificial habitat" (künstliches Habitat) in which, like an actor, the reader can move with a certain degree of freedom. Readers can thus restructure their own hierarchies of aesthetic, ethical and political values. In this context, the aesthetic component of experience performs in particular the function of fluidifying the complex of other values, so that it is possible to shape a new configuration of life (Jauss 1972). In this sense, aesthetic values present themselves as meta-values of human experience. L'assemblea degli animali essentially insists on the meeting point between media and the dimension of affectivity widely understood, and interprets this relationship in terms of an overlapping between the sphere of human communication and the sphere of interspecific communication, between the cultural environment and natural environment.

At this level, the ambiguity of the book emerges. It is the same ambiguity that runs through the rhetoric of the rediscovery of the nature of progressive, intellectual and even philosophical discourse (cf. Coccia [2020] among others). The starting point is not problematic, which is indisputable: the defense of the environment requires a decisive change of gear in the industrial policies of developed countries. This is a priority on the 
global political agenda. Problematic are the point of arrival and the ideological substrate, if you can call it that, connected to this rhetoric. The latter often ends up identifying the "metamorphosis" of the human with the uncritical re-appropriation of an alleged animality, or even a lost "vegetality" (Coccia [2018]; Mancuso [2019]). A problematic element of these philosophies emerges, for example, in the latest formulation of his thought program by Emanuele Coccia (2020). Here, the notion of metamorphosis has both a descriptive value and a normative value at the same time: it indicates belonging to a cycle of natural transformations and the imperative to a return to the origin. L'assemblea degli animali relaunches this contradiction, or perhaps indicates its place of origin: the question should not be sought so much in the conflict between nature and culture, between ecology and progress, but in the short circuit between communication and information, between the sphere of the media and the culture of sharing and the sphere of knowledge and critical knowledge. Filelfi are placed here, but they are not the wise guardians of an ancient wisdom: they are skilled users of the internet, at times shrewd at times (maybe intentionally, or just luckily) naïve.

\section{REFERENCES}

Bachtin, M., 1981: The Epic and the Novel: Towards a Methodology for the Study in the Novel, in Id., The Dialogic Imagination, ed. by M. Holquist, University of Texas Press, Austin.

Bolter, J.D., 2019: The Digital Plenitudine. The Decline of the Elite Culture and the Rise of the New scenario Media, MIT Press, Cambridge (Mass.).

Cappelletto, C., 2021: Arguments for a New Aesthetics of Presence, "Critical Inquiry", n. 47, pp. 100-3.

Coccia, E., 2020a: The Life of Plants. A Metaphysics of Mixture, trans. eng. by D.J. Montanari, Polity, Cambridge 2018.

Coccia, E., 2020b: Métamorphoses, Payot \& Rivages, Paris.
Desideri, F., 2018: Origine dell'estetico. Dalle emozioni al giudizio, Carocci, Roma

Eco, U., 1979: Lector in fabula: la cooperazione interpretativa nei testi narrativi, Bompiani, Milano.

Filelfo, 2020: L'assemblea degli animali. Una favolta selvaggia, Einaudi, Torino.

Frankfurt, H.G., 2005: On Bullshit, Princeton University Press, Princeton.

Garroni, E., 2003: Comprendere e narrare, in Id., L'arte e l'altro dall'arte, Laterza, Roma-Bari, pp. 175-197.

Garroni, E., 2005: Immagine Linguaggio Figura. Osservazioni e ipotesi, Laterza, Roma-Bari.

Grusin, R., 2015: Radical Mediation, "Critical Inquiry”, Vol. 42, No. 1 (Autumn), pp. 124148.

Iser, W., 2015: Kultur. Ein emergentes Phänomen, in Id., Emergenz. Nachgelassene und verstruet publizierte Essays, ed. by A. Schmitz, Konstanz University Press, Konstanz.

Jameson, W., 1991: Postmodernism, or The Cultural Logic of Late Capitalism, Duke University Press, Durham.

Jauss, H.R., 1972: Kleine Apologie der ästhetischen Erfahrung, Universitätsverlag, Konstanz, pp. 227-245.

Lyotard, J.-F., 1984: The Postmodern Condition. A Report on Knowledge, trans. eng. by G. Bannington, B. Massumi, University of Minnesota Press, Minneapolis.

Mancuso, S., 2019: La nazione delle piante, Laterza, Roma-Bari.

Montani, P., 2007: Bioestetica. Senso comune, tecnica e arte nell'età della globalizzazione, Carocci, Roma.

Ricoeur, P., 1983: Temps et récit 1, Seuil, Paris. 